\title{
The ethics of dental practice in London in the sixteenth century. 2. Sir Thomas More's 'Ordinances' for the Barber-Surgeons, 1530.
}

IN BRIEF

- Shows regulation of health care by the state through a specialist guild.

- Provides the background against which Chettle's independent tooth-drawer can be seen.

- Shows the benefit to the public of supervised health-care provision.

- Shows the benefit to the provider of structured education and much else.

\section{Bishop ${ }^{1}$}

Sir Thomas More's Ordinances can tell us much about London dental practice in the sixteenth century, providing an overview of training, development and practice within a healthcare service much like our own.

\section{INTRODUCTION}

The ordinances of Sir Thomas More, ${ }^{1}$ (Fig.1) which were promulgated in 1530 for the Company of Barbours Surgeons of London, represent an ideal of state oversight for an organisation delivering healthcare services from fixed and clearly identified premises. They cover professional training, public health protection, continuing professional development, practice inspection and much else. Many of the persons involved, apart from Sir Thomas More himself, who was painted separately by Holbein, can be seen in the 1540 Holbein painting at the Barbers Hall (copy at the Royal College of Surgeons).*

When, in 1540, the separate functions of barbery and surgery were defined within the company, ${ }^{2}$ and tooth-drawing, although a surgical procedure, was permitted to those working as barbers, the stable environment in which much early development of the dental functions of healthcare took place was established. (Somewhat confusingly, the 1540 Act united the Surgeons Company (small in numbers) with the Barbour-Surgeons, and their separate functions needed to be clearly defined).

*For a full critique see Cohen B. King Henry VIII and the Barber Surgeons: the story of the Holbein Cartoon. Ann R Coll Surg Engl 1967; 40: 179-194. In addition to: Cohen B. A tale of two paintings. Ann R Coll Surg Engl 1982; 64: 4-12.

${ }^{1}$ Bulls Mill House, Hertford, SG14 3NS

Correspondence to: Malcolm Bishop

Email:malcolmbishop57@btinternet.com

\section{Refereed Paper}

Accepted 4 May 2012

DOI: 10.1038/sj.bdj.2012.616

${ }^{\circ}$ British Dental Journal 2012; 213: 77-80
Modern dentistry in the UK is a product of a marriage between the ethos of the independent tooth-drawer of the type Chettle describes in the person of KindHart, ${ }^{3}$ and the providers of dental services whose self-government was limited by the type of statute first established by Sir Thomas's Ordinances.

Examples of the latter type of practitioner may be found two centuries later in Hogarth's illustration of a barbers' establishment at Charing Cross, where Robert Wood, Richard Legg (c1678-?), and John Sangwin (c.1792-1747), shaved, bled, and drew teeth for well over 50 years. ${ }^{4}$ The highest point of achievement for dental specialists came with the elevation of Samuel Rutter (1696-1761), who called himself a tooth-drawer, to the Mastership of the Barber-Surgeons Company in 1745 .

It was too late. The opportunity for the profession to become separately established under the particular (and in theory at least) exemplary governance umbrella of the barber-surgeons was lost in that year with the departure of the surgeons ${ }^{5}$ - who did not welcome operators for the teeth (as the early dentists termed themselves) or dentists for many years, and then only with the greatest reluctance. ${ }^{6}$ The baton of dentistry as an ethical profession passed back to the spiritual successors of KindHart for more than a hundred years, from 1745 until 1860.

\section{LIMITED SELF-GOVERNANCE}

The state, being reformed under Henry VII with a civil service shaped by Cardinal

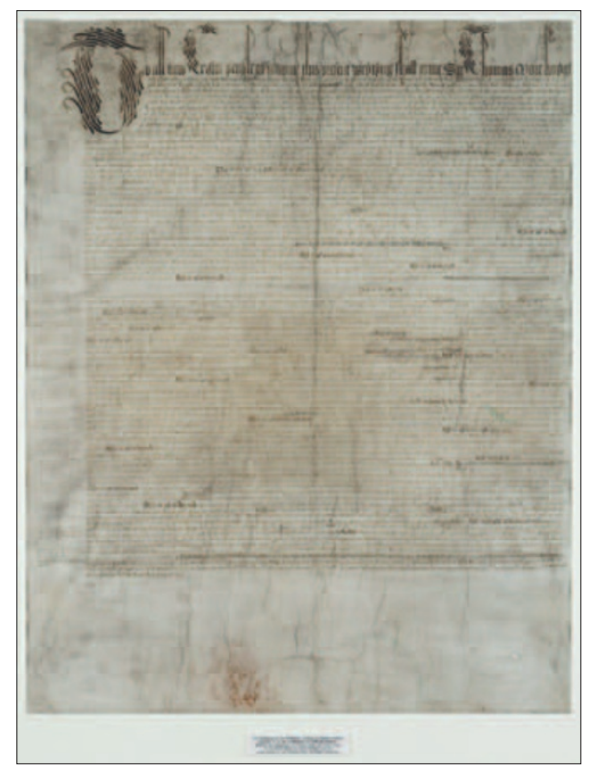

Fig. 1 Sir Thomas More's Ordinances. 14th May 1530. Reproduced by kind permission of the Worshipful Company of Barbers of London

Wolsey and his successor Sir Thomas More, was prepared to take a firm hand in the control of the administration of guild behaviour, as seen in the Act of 1503 For making of statutes by bodies incorporate. ${ }^{7}$ It is as a direct consequence of the requirements of this Act that under Henry VIII the Ordinances for the Barber-Surgeons were prepared in 1530.

It is fortunate for the dental historian, given the curious hybrid position of the barber-surgeons where both surgeons and, as noted above, barbers, could undertake dental operations, that More's careful review of the ordinances of the 'fellowship' defined the ethical structure of a healthcare provider which, like dentistry, was a mixture of trade and learned profession. ${ }^{8}$ 
The Ordinances are written on a single vellum sheet preserved at the Hall of the Honourable Company of Barbers at Monkwell Square in London, a remarkable and very precious survival through war and civil unrest. As a legal document, there is neither pagination, nor paragraphs, and no gaps, so all references are to pages in the transcript made by Sidney Young in $1890 .{ }^{1}$

Most of the quotations have been paraphrased here into modern English. Chettle's English, although written only seventy years later, can be left intact and be easily understood. The same is not true of the English of the Ordinances.

Nevertheless, the modernity of the Ordinances transcends the language in which they were phrased, for example continuing professional development is compulsory in the seventeenth Ordinance;

'It is ordained that every man enfranchised in the Fellowship and practising Surgery shall come to their Hall to the reading of the lecture concerning surgery every day it assembles. And every man in due course shall read the lecture himself or else find an able man of the said Fellowship to read it for him, and not to absent himself at his day of reading without reasonable cause, and without giving lawful warning before the day on pain of forfeit for every time 20 shillings.' (A living wage was then 50 shillings a year). ${ }^{9}$

It was for these lectures that the great John Caius later gave his anatomy demonstrations, and at the division of the surgeons and the barbers in 1745, endowments for the delivery of lectures went with the surgeons.

\section{THE PREAMBLE AND OATHS}

The Ordinances were not created from new and the preamble shows that in accordance with the 1503 Act, the Masters and Governors of the Fellowship of BarberSurgeons had submitted their old ordinances for review. Leaving these lines in the original form gives an idea of the phrasing of the whole document;

'Willing and desiring the said Acte in every behalff to be observed and kept the xxth day of Octobre in the xxjth yere of the Raigne of owre Soueraigne lorde Kyng Henry the viijth have exhibite and presented their peticion thereupon made with a Boke conteyning dyvers Statutes Actes and Ordinances hertofore devised ordeyned and made for the ffelauship of Barbors Surgions and their Successors. ${ }^{10}$

The preamble continues, to show that the new ordinances are no mere rubberstamping of the old; "every one examined, corrected, and reformed, as follows.. ${ }^{11}$

Then the oaths to be taken by the freemen of the fellowship, and by the masters and governors, are given. Of particular interest in the oath of the masters is the obligation to carry out "practice inspections' and see that any shortfall is remedied. The annual visit of the regional dental officer (RDO) will be called to mind by many.

'You shall duly and truly search through all the Company of the same Craft within the City of London and its Suburbs."11

\section{THE ORDINANCES}

After the preamble and the oaths, the ordinances themselves are laid out. There are 22 of them and those which deal with professional ethics are of particular interest to the present study.

Practice inspections have already been covered above and are also implied in the tenth ordinance, where the announcement of the location of the practice and agreement to payment of a retention fee is mandatory; 'it is Ordained that no person of the Fellowship, after he has been admitted and sworn Freeman of this City before the Chamberlain, presume to open his Shop Windows before he has presented himself to the Masters or Governors of the Mistery for the time being, and with them has agreed in paying his due.'12

The details of this quarterly retention fee are laid out in the third ordinance, both for those in livery and those without, which included widows keeping the practice going. In this ordinance and in any other where fines were imposed, the fine (keeping in mind the living wage of 50 shillings a year, a heavy one) was divided between the Alms of the Fellowship and the Chamber of London, so although the provision of sickness benefits and dependants benefits is not given a separate ordinance, it is catered for throughout. The Benevolent Fund of the BDA, though voluntary, is comparable.

'It is enacted and ordained that every liveryman shall pay quarterly to the maintenance of the common charges of the Company 6 pence. Those not liverymen, and every widow keeping an open shop, 3 pence.

These sums to be paid quarterly, upon pain of forfeiting at every time not doing so 3 shillings and 4 pence, half of which to be applied to the Chamber of London, and the other half to the Alms of the Fellowship on condition that the Quarterage be properly demanded. ${ }^{13}$

The fourth ordinance made it mandatory that the health of apprentices was to be checked before they were enrolled, both for chronic illness and infectious disease. It is thus clear from the evidence that the Tudors had a clear idea of preventive medicine and were prepared to take action to limit cross infection. This attitude was reinforced by the later separation of functions between barbers and surgeons, so that those being shaved did not come into contact with either the sick or those treating them:

'Also it is ordained that no person enfranchised of the craft shall take any apprentice before that apprentice has been presented to the masters or Governors to confirm that he is clean and without chronic disease or serious infirmity whereby the King's people might take hurt. The fine for failing to do so being 11 shillings. ${ }^{14}$

Of a similar kind, but relating to patients, is ordinance sixteen, which covers both infectious disease and trauma, which might lead to permanent disability. Within four days of any barber-surgeon taking in a patient for cure who was in peril of death or maim, a second opinion must be sought from two of the masters and governors of the fellowship. The importance of this ordinance is underlined by the imposition of the highest fine for failure to comply of any in the list: 20 shillings (one pound).

Ordinances six and seven ensured that no master in livery could take on more than four apprentices or assistants at a time, or three if the master was not liveried. This had a double effect. The master could not have more apprentices than he could reasonably instruct, and could not, by taking on many assistants, run what in 21 st century terms would be called a body corporate. To allow for continuity the master was permitted to have a replacement apprentice or assistant overlapping the leaving member of the team by six months. 
'Also it is ordained that no liveryman shall have any more assistants (Servauntes) apprentices or Covenants [Covenant Servants, servants or assistants engaged under covenants to serve for a period (generally two years) and whose engagements were recorded by the Clerk at the Hall] practising Barbery or Surgery at any one time than four. Providing always that within six months of the ending of the term of one of these four it is lawful to take on another apprentice or assistant. ${ }^{14}$

For those out of livery, the number was reduced to three. The fine (11 pence) for breaking the rule was not reduced.

The eighth ordinance required that any barber or surgeon from abroad (in the widest sense, an Englishman from outside London or Aliaunt Straunger [foreigner]) joining a liveryman must be presented to the masters or governors within three days. The ninth ordinance required that at that time his wages were to be fixed, and that from those wages, 3 shillings and 4 pence were to be deducted by the master to be paid quarterly into the Alms of the Fellowship. Luring or enticing a servant from another master was forbidden, as was employment of any assistant for a period of less than a year. The penalty was one mark sterling (13 shillings and 4 pence). ${ }^{14}$

The tenth ordinance insisting on the equivalent of practice inspection has already been described. The eleventh continues on the theme of training, echoing the Hippocratic oath with its undertaking to teach the secrets of medicine; "to disciples bound by a stipulation and oath according to the law of medicine, but to none other'. ${ }^{15}$

'No one enfranchised in the Mystery shall inform or teach anyone other than his apprentice any aspect of the craft of Barbery or Surgery. The penalty for so doing being 11 shillings on each occasion. ${ }^{16}$

Three hundred years on, liberation from this restriction following the effective exit of dentists from the Barber-Surgeons Company, allowed the American Levi Spear Parmly to advertise in 1820 what was almost certainly the first dental school in London, at Number 1, St James's Street. ${ }^{17}$ The fee, a high one, was 200 guineas (reduced for practice in the provinces or abroad). Apprenticeship, however, persisted as the norm for training dentists, and the potential for harm in such limited teaching was regretted by the reformers of the 19 th century.

of more than particular interest are the requirements of ordinances twelve, thirteen and eighteen. These deal with the ethics of professional conduct between practitioners and between practitioners and their patients. In ordinance eighteen it is made clear that a patient is at liberty to choose freely who is to treat him or her and may leave a practitioner at any stage of the treatment so long as the fee is paid, and go to another:

'If the patient (pacyent) finds himself aggrieved with his surgeon, then the patient having paid the first surgeon reasonably for his work may go to any other Surgeon he chooses.'

At the same time, no practitioner 'may take any cure [person under treatment] from another of the same Fellowship nor supplant another. ${ }^{9}$

It should be noted that there are three types of dispute which were strongly discouraged, each with a suggested resolution. First, "no man of the said fellowship shall give or speak any slanderous words to the denigration of the science or cunning of another, but rather be in readiness to give good council to help the King's people' ${ }^{9}$ Positively, this encouraged a practitioner to support his colleagues, and failure to do so was met with a penalty of one mark sterling (13 shillings and 4 pence). Second, no practitioner should run down another either in public or in the hearing of the Masters and Governors of the Fellowship. The penalty for this was less, at 6 shillings and 4 pence. Third, if a dispute between practitioners showed signs of getting out of hand, a cooling off period of thirteen days was to be observed after putting the case before the masters or governors. Only after that was recourse to common law to be undertaken. The fine for not observing this was one mark.

'If any matter of strife or debate be between any person of the said Craft, God forbid that any of them raise the matter under the Common Law. The person aggrieved shall first make his complaint known to the Masters or Governors in order that they may sort out the matter. Only if they are unable to do so within 13 days shall it be lawful for the matter to be referred to the Common Law' ${ }^{16}$
Ordinance fifteen forbade any freeman of the company from performing shaving on Sundays either at his shop or at anyone's home. ${ }^{16}$ No mention is made of the healing function, and the distinction is important. There was a mandatory day of rest from the trade function of the barber-surgeon, and notably, his assistants. The healing function was permissible on any day.

Of the remaining ordinances, those dealing with common assembly and precedence (numbers one and two had dealt with the discipline of responding individually to a summons from the masters of governors) seem charming and quaint until it is recognised that these assemblies served the purpose of the modern Dentists' Register (the register of the time was not in general circulation, but kept at the Hall) whereby every freeman knew his fellows, and was in turn known by them and the masters.

'And where by custom each year on the Sunday after the Feast of St. Bartholomew the Apostle $e^{*}$ a dinner is held for the Livery of the Company at the Barber's Hall, and on the Saints Day of Cosmas and Damian ${ }^{\S}$ (unless it is a Saturday) a dinner for those of the Company not in Livery, it is ordained that every man who has been the Master or Upper Governor of the Company shall pay at and for the dinner twelve pence for himself, and eight pence for his wife if she comes.

And everyone else being of the Livery of the Company shall pay eight pence for himself, and fourpence for his wife if she comes.

Provided always that the current Master or Governors of the Company shall pay nothing for their wives coming to the dinner, since their wives must of necessity be there to help that everything is set in order.

Every man of the Company not in Livery shall pay eight pence, and for his wife fourpence, if she comes. ${ }^{18}$

\section{CAVEATS}

The first of the caveats which bring the Ordinances to a close is a standard rehearsal of the limitations of the Act in relation to

${ }^{\dagger}$ Associated with medicine and healthcare. Martyred 1st century possibly in Armenia. Saint's day August 24th (St Bartholomew's Fair held at Smithfield was where Kind-Hart practised)

TTwin physicians martyred in Syria c. 287 AD. Famous for reputedly transplanting a leg. Saints' Day September 26th 
the powers granted to the City of London. However, there is an interesting addition, to the effect that no-one could set up shop as an independent barber (surgeons are not mentioned here) without adequate financial means, to the clear value of ten marks sterling. The penalty was 11 shillings. ${ }^{19}$ As with all the other fines, half went to the Chamber of London, half to the company's alms. As this shows, the Company of Barber-Surgeons of London, for all its special conditions, was an associate member of the Chamber of London.

\section{SUMMARY}

The first of these two papers championed the fully independent dental practitioner as seen in Chettle's hero Kind Hart. This paper presents, if not a contrary view, at least a clear outline of the very great benefits to state and operator of a clearly defined structure of legal governance.

Up until the Act of 1540, which united the surgeons and the barber-surgeons, the latter group (superior in numbers if not in status) acted as the general practitioners of the day. As a consequence of their hybrid nature, barbers in the city were in a beneficial position. Due to their regular shaving contact with their potential patients while they were not sick or distressed, they, like the dentist who is equally privileged to treat the healthy and get to know them, had an established position of trust if something less pleasant was needed than barbering. The tooth-drawer, even one as competent as Kind-Hart, only saw his patients when in distress, and was much less likely to be in the same position as those barbers who took an interest in dentistry and were able to extend their services to scaling and restoration.

After the break-up of the BarberSurgeons Company in 1745, the new dentists preserved at least the structure of apprenticeship, though the community of the guild was sorely missed.

Apart from providing evidence of the secular governance of a branch of medicine in early modern times, the Ordinances of the Barber-Surgeons when broken down in this way, provide a model for the administration of a quasi-autonomous professional body.
For a model of the sort of governance which the reformers of 1841 were seeking, they were an ideal to be dreamed of; for all that they were by then three hundred years old. They prescribe the ethical rules for:

- Internal discipline

- Conciliation pathways for intra-professional disputes

- Practice inspection

- Continued professional development

- A retention fee

- Education pathways

- Formal enrolment of students (apprentices)

- Registration of ancillary staff

- Limitation of numbers of apprentices and assistants

- Insurance for sickness and dependants

- Communal meetings

- Mandatory rest day for trade activity (though not for the healing function)

- Liberty for patients to choose their carer

- 'Poaching' of patients forbidden

- Criticism of colleagues' clinical procedures forbidden

- No setting up in independent practice without adequate funding

Thanks to the two sixteenth century documents described in these papers, those privileged to practise dentistry more than four centuries later can see both in the personality of Kind-Hart and in the governance of the barber-surgeons, admirable models on which to base their own professional lives and activity.

\section{BIBLIOGRAPHY}

Note: The preparation and presentation of historical papers has been revolutionised by the internet. The location of original documents such as Chettle's Kind-Harts Dreame and Sir Thomas More's Ordinances is given in the text and references, but the interested reader may find transcriptions freely available on line. (Care has generally been taken to make sure these transcriptions are accurate, but occasional misreadings are possible. The originals retain their importance.)

The Percy Society's 1841 transcription, with notes, of Chettle's Kind Harts Dreame may be found at: http://www.archive.org/ details/earlyenglishpoet05perc
Young's Annals of the Barber-Surgeons with the Ordinances transcribed as Appendix B, (pp 579-586) may be found at http://www.archive.org/details/ annalsofbarbersu00youn

1. Original at the Hall of the Worshipful Company of Barber Surgeons of London. Transcription in Young $\mathrm{S}$ The annals of the Barber-Surgeons of London compiled from their records and other sources. Appendix B. pp 579-586. London: Blades East \&t Blades, 1890.

2. Henry VIII c.42. An Act concerning barbours and surgeons to be of one companie. London: 1540.

3. Bishop M. The ethics of dental practice in London in the sixteenth century. 1. Henry Chettle's Kind-Harts Dreame of 1592. An important lay view. Br Dent J 2012; 213: 27-30.

4. Bishop M. A picture of dentistry at Charing Cross in the 1730's given by Hogarth's painting and print of Night. Professional governance, identity and possible mercury intoxication as an occupational hazard for his barber tooth-drawer. Br Dent J 2007; 203: 265-269.

5. George II c15. An Act for making the surgeons of London and the barbers of London two separate and distinct corporations. London: 1745.

6. Bishop M, Parker M. Sir John Tomes FRS, Fellows of the Royal Society and dental reform in the nineteenth century. Notes Rec R Soc Lon 2010; 64: 401-416.

7. Henry VII c.7. For making of statutes by bodies incorporate. London: 1503.

8. Samson E. Progressive practice. A treatise on dental economics. London: Cottrell, 1931.

9. Young S. The annals of the Barber-Surgeons of London compiled from their records and other sources. Appendix B. pp 584. London: Blades East Et Blades, 1890.

10. Young S. The Annals of the Barber-Surgeons of London compiled from their records and other sources. Appendix B. pp 579-580. London: Blades East \& Blades, 1890.

11. Young S. The Annals of the Barber-Surgeons of London compiled from their records and other sources. Appendix B. p 580. London: Blades East \&t Blades, 1890.

12. Young S. The Annals of the Barber-Surgeons of London compiled from their records and other sources. Appendix B. pp 582-583. London: Blades East \& Blades, 1890.

13. Young S. The Annals of the Barber-Surgeons of London compiled from their records and other sources. Appendix B. p 581. London: Blades East \&t Blades, 1890.

14. Young S. The Annals of the Barber-Surgeons of London compiled from their records and other sources. Appendix B. p 582. London: Blades East \& Blades, 1890.

15. Hippocrates. The Hippocratic oath. Late 5th century BC.

16. Young S. The Annals of the Barber-Surgeons of London compiled from their records and other sources. Appendix B. p 583. London: Blades East Et Blades, 1890.

17. Parmly LS. Lectures on the natural history and management of the teeth: the cause of their decay, the art of preventing its accession and the various operations hitherto suggested for the preservation of such teeth as it is too frequently considered necessary to extract. Facing p.96. London: Burgess and Hill, 1820.

18. Young S. The Annals of the Barber-Surgeons of London compiled from their records and other sources. Appendix B. pp 584-585. London: Blades East \&t Blades, 1890.

19. Young S. The Annals of the Barber-Surgeons of London compiled from their records and other sources. Appendix B. p 586. London: Blades East \&t Blades, 1890. 